\title{
Histomorphometrical and ultrastructural study of the effects of carbendazim on the magnum of the Japanese quail (Coturnix coturnix japonica)
}

\author{
Authors: \\ Wahabu H. Kimaro ${ }^{1,2}$ \\ Mary-Catherine \\ Madekurozwa ${ }^{1}$ \\ Herman B. Groenewald ${ }^{1}$ \\ Affiliations: \\ ${ }^{1}$ Department of Anatomy \\ and Physiology, University of \\ Pretoria, South Africa \\ ${ }^{2}$ Department of Veterinary \\ Anatomy, Sokoine University \\ of Agriculture, Tanzania \\ Correspondence to: \\ Wahabu Kimaro \\ Email: \\ kim16wh@yahoo.com \\ Postal address: \\ Private Bag X04, \\ Onderstepoort 0110, \\ South Africa \\ Dates: \\ Received: 20 Feb. 2013 \\ Accepted: 29 Apr. 2013 \\ Published: 19 July 2013 \\ How to cite this article: \\ Kimaro, W.H., Madekurozwa, \\ M-C. \& Groenewald, H.B., \\ 2013, 'Histomorphometrical \\ and ultrastructural study of \\ the effects of carbendazim \\ on the magnum of the \\ Japanese quail (Coturnix \\ coturnix japonica)', \\ Onderstepoort Journal of \\ Veterinary Research 80(1), \\ Art \#579, 8 pages. http:// \\ dx.doi.org/10.4102/ojvr. \\ v80i1.579

\section{Copyright:} \\ (C) 2013. The Authors. \\ Licensee: AOSIS \\ OpenJournals. This work \\ is licensed under the \\ Creative Commons \\ Attribution License. \\ Read online:

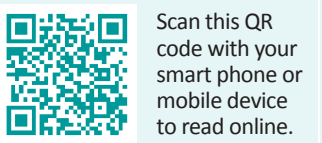

The study investigated the effect of various doses of carbendazim on the morphology of the magnum of the Japanese quail. No morphological changes were observed in the magnum in birds treated with carbendazim at doses of $25 \mathrm{mg} / \mathrm{kg}$ and $100 \mathrm{mg} / \mathrm{kg}$ bodyweight. A carbendazim dose of $400 \mathrm{mg} / \mathrm{kg}$ bodyweight was the lowest dose which caused morphological changes in the magnum. Histologically, carbendazim caused pyknosis and glandular atrophy in the magnum mucosa. Carbendazim also caused significant decreases in the height of the mucosal folds, epithelial height, glandular width and glandular luminal diameter at $400 \mathrm{mg} / \mathrm{kg}$ and $800 \mathrm{mg} / \mathrm{kg}(p<0.05)$. At ultrastructural level, dose-dependent deciliation was observed. Pyknotic nuclei, dilated cisternae of rough endoplasmic reticulum, swollen mitochondria, numerous vacuoles and lysosomes in the luminal and glandular epithelia were identified. The observed degenerative changes could be due to cytoskeletal disruption caused by carbendazim toxicity. Degeneration of the luminal and glandular cells in the magnum pose a potential threat to the egg production and reproduction of exposed birds.

\section{Introduction}

Carbendazim (methyl-2-benzimidazole carbamate) is a derivative of the benzimidazole group of fungicides, which are N-substituted esters of carbamic acid (carbamate). Carbendazim is also a metabolite of benomyl (methyl-1-butylcarbamoyl) when dissolved in water. Both chemicals (carbendazim and benomyl) are used as fungicides on ornamental plants, vegetables, fruits and cereals (International Program on Chemical Safety [IPCS] 1986). The fungicidal effect of these chemicals relies on their ability to disrupt microtubule assembly (Davidse \& Flach 1977; Burland \& Gull 1984). According to the Finnish National Board of Health report (1982), the level of benomyl and carbendazim metabolites such as methyl (4-hydroxy-1H-benzimidazol-2-yl) carbamate, methyl (5-hydroxy-1H-benzimidazol-2-yl) carbamate and 4,5-dihydrodiol-MBC in food and water is increasing. Carbendazim metabolite residues are present in plants (Still \& Mansager 1975), soil (International Program on Chemical Safety [IPCS] 1986), surface and ground water (IPCS 1986) and fruits (Pico et al. 2007). Due to the increasing concentrations of benomyl and carbendazim metabolites in the environment, it is likely that aquatic and terrestrial organisms are being exposed to carbendazim metabolites.

The magnum is the longest region of the avian reproductive tract, making up to $50 \%$ of the total oviductal length in domestic fowls (Wyburn et al. 1970). The magnum releases egg-white proteins such as ovalbumen, conalbumen, ovomucoid, lysozyme and avidin (Palmiter \& Gutman 1972). Davidson (1986) reported the production of watery eggs associated with morphological changes in the luminal and glandular epithelia of the magnum. It is clear that morphological changes in the magnum will adversely affect the quality of eggs, as well as the egg laying process.

Carbendazim causes morphological changes in mammalian reproductive organs (Carter \& Laskey 1982; Goldman et al. 1989; Hess et al. 1991; Lim \& Miller 1997) and male birds (Aire 2005). Little is known on the effect of carbendazim in the reproductive tract of female birds. This study therefore reports the effect of various doses of carbendazim on the morphology of the magnum of the Japanese quail.

\section{Materials and methods}

\section{Animal management and sample collection}

A total of 35 sexually mature female Japanese quail (Coturnix coturnix japonica) were purchased from Irene Improvement Research Farm, Pretoria. The birds were housed in an avian facility and allowed to breed freely. Both males and females were kept together. After acclimatisation at the research site, the birds were divided into two groups, the control (seven birds) and 
treatment groups (28 birds). The treatment group was further divided into four groups of seven birds each, according to the dose administered. Carbendazim (97\% Sigma Aldrich) was dissolved in sunflower oil and administered once per os to the four experimental groups at doses of $25 \mathrm{mg} / \mathrm{kg}$, $100 \mathrm{mg} / \mathrm{kg}, 400 \mathrm{mg} / \mathrm{kg}$ and $800 \mathrm{mg} / \mathrm{kg}$ bodyweight respectively. The doses were selected based on a previous experiment on male Japanese quails (Aire 2005). Control birds were given only the sunflower oil base orally. During the experiment, food (grower mash, containing maize grain) and water were provided ad libitum. Light was controlled at $14 \mathrm{~h}$ light and $10 \mathrm{~h}$ darkness throughout the experiment.

Forty-eight hours post-exposure to carbendazim, the birds were sacrificed by inhalation anaesthesia using carbon dioxide $\left(\mathrm{CO}_{2}\right)$. Following the death of a bird, the thoracoabdominal cavity was opened and the reproductive tract was dissected out immediately. The protocol of this research (\# V031/07) was approved by the animal use and care committee (AUCC) of the University of Pretoria.

\section{Light microscopy studies}

Tissue samples from the middle part of the magnum were fixed in $10 \%$ buffered formalin for $48 \mathrm{~h}$. Tissue samples were then processed routinely for light microscopy (Drury \& Wallington 1976) using an automated tissue processor (Shandon excelsior ${ }^{\circledR}$, Thermo Electron Corporation, Germany). After staining with haematoxylin and eosin (H\&E), sections of the tissue samples were examined under bright field light microscope (Olympus $\mathrm{BH}-2$ ) at a magnification $40 \times$ and/or $100 \times$ for histopathological changes. In addition, tissue morphometry such as the height of primary folds, epithelial height, tubular gland width and glandular luminal diameters were evaluated at magnification $20 \times$ and/or $40 \times$ using an image analyser (AnalySIS ${ }^{\circledR}$; Olympus BX 50, Optical Company LTD, Japan). The height of a primary fold was measured by drawing a vertical line from the base to the luminal end (Figure 1). Epithelial height was determined by measuring the height of 15 cells in five different primary folds (Berg et al. 2001). The individual glandular width was measured by drawing a perpendicular line across the widest part of the gland (Figure 1). Glandular luminal diameter was determined by measuring the perpendicular distance between two opposing gland cells. Morphometrical data were analysed using analysis of variance (ANOVA), SPSS version 17 . A probability of $5 \%$ was considered significant. Photomicrographs were taken using a CC-12 digital camera mounted on the image analyser.

\section{Scanning and transmission electron microscopy studies}

Tissue samples from the middle part of the magnum were immersion fixed in $2.5 \%$ glutaraldehyde in $0.1 \mathrm{M}$ Millonig's buffer ( $\mathrm{pH} 7.3$ ) for $48 \mathrm{~h}$. The tissue samples were subsequently post-fixed in $2.0 \%$ osmium tetroxide for $2 \mathrm{~h}$. After dehydration in graded concentrations of alcohol, tissue samples were processed for scanning electron microscopy (SEM) and transmission electron microscopy (TEM) using standard techniques. Samples for SEM were viewed and photographed with a Philips XL20 scanning electron microscope. The transmission electron microscopy samples were viewed and photographed with a Philips CM10 electron microscope.

\section{Results}

\section{Tissue morphometry}

Morphometric data measured in the control and carbendazim treated birds are summarised in Table 1.

\section{Control birds}

The height of primary folds in the magnum measured between $234.84 \mu \mathrm{m}$ and $515.88 \mu \mathrm{m}$ (mean $378.23 \pm 21.3$ ). The height of the luminal epithelium ranged from $15.72 \mu \mathrm{m}$ to $31.51 \mu \mathrm{m}$ (mean $22.98 \pm 0.25)$. The width of glands measured between $22.99 \mu \mathrm{m}$ and $49.12 \mu \mathrm{m}$ (mean $33.96 \pm 0.84$ ). The glandular luminal diameters varied from $2.04 \mu \mathrm{m}$ to $23.12 \mu \mathrm{m}$ (mean $11.47 \pm 0.81)$.

\section{Carbendazim-treated birds}

There was a general decrease in the height of primary mucosal folds in carbendazim-treated groups. The decrease was significantly different at doses of $400 \mathrm{mg} / \mathrm{kg}$ and

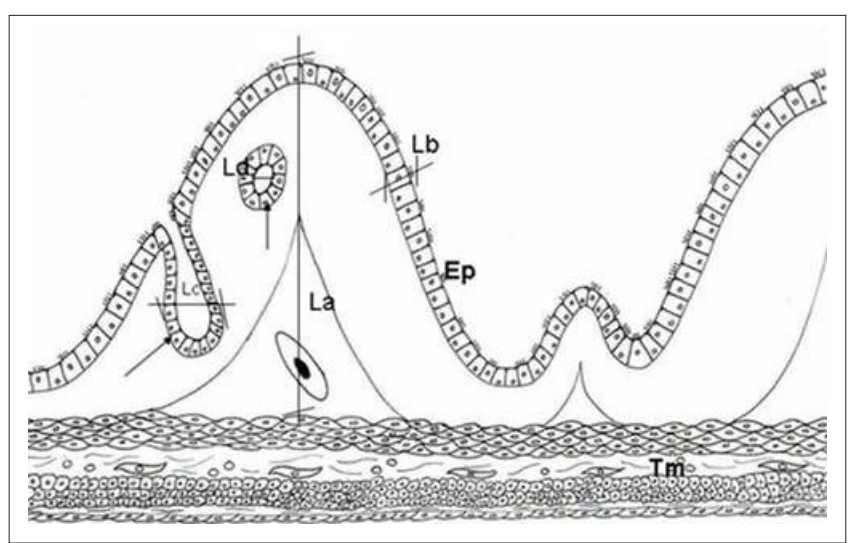

Ep, luminal epithelium; Arrows, tubular glands; Tm, tunica muscularis. The height of the mucosal fold, luminal epithelium and glandular width are shown by lines $\mathrm{La}$, $\mathrm{Lb}$ and $\mathrm{LC}$ respectively. Glandular luminal diameter is indicated by $L d$.

FIGURE 1: Schematic drawing of the oviductal mucosa of the Japanese quail.

TABLE 1: Histomorphometrical parameters (mean \pm standard error) in the magnum of control and carbendazim-treated Japanese quails.

\begin{tabular}{lllll}
\hline Dose $(\mathrm{mg} / \mathrm{kg})$ & Mucosal fold $(\mu \mathrm{m})$ & Epithelial height $(\mu \mathrm{m})$ & Gland width $(\mu \mathrm{m})$ & Luminal diameter $(\mu \mathrm{m})$ \\
\hline 0 & $378.23 \pm 21.34$ & $22.98 \pm 0.25$ & $33.96 \pm 0.84$ & $11.47 \pm 0.81$ \\
25 & $306.97 \pm 19.21^{\mathrm{b}}$ & $22.22 \pm 0.31^{\mathrm{b}}$ & $32.71 \pm 0.93^{\mathrm{b}}$ & $6.34 \pm 0.39^{\mathrm{a}}$ \\
100 & $315.77 \pm 23.29^{\mathrm{c}}$ & $19.66 \pm 0.29^{\mathrm{a}, \mathrm{c}}$ & $26.35 \pm 0.99^{\mathrm{a}, \mathrm{b}, \mathrm{c}}$ & \\
400 & $184.16 \pm 84^{\mathrm{a}, \mathrm{b}, \mathrm{c}}$ & $15.19 \pm 0.63^{\mathrm{a}, \mathrm{b}, \mathrm{c}}$ & $27.3 \pm 0.77^{\mathrm{a}, \mathrm{b}}$ & $6.51 \pm 0.26^{\mathrm{a}, \mathrm{b}}$ \\
800 & $142.08 \pm 9.83^{\mathrm{a}, \mathrm{b}, \mathrm{c}}$ & $8.53 \pm 0.19^{\mathrm{a}, \mathrm{b}, \mathrm{c}}$ & $30.09 \pm 0.86^{\mathrm{a}, \mathrm{c}}$ & $7.59 \pm 0.35^{\mathrm{a}, \mathrm{b}}$ \\
\hline
\end{tabular}

a, Differ significantly from control; b, A significant change between carbendazim treatment groups; $c$, A significant change between carbendazim treatment groups. 
$800 \mathrm{mg} / \mathrm{kg}$ bodyweight carbendazim when compared to the control group (Table 1). A significant decrease in the height of the mucosal folds was also observed between carbendazim treatment groups, such as: $25 \mathrm{mg} / \mathrm{kg}$ and $400 \mathrm{mg} / \mathrm{kg}$; $25 \mathrm{mg} / \mathrm{kg}$ and $800 \mathrm{mg} / \mathrm{kg} ; 100 \mathrm{mg} / \mathrm{kg}$ and $400 \mathrm{mg} / \mathrm{kg}$, as well as, $100 \mathrm{mg} / \mathrm{kg}$ and $800 \mathrm{mg} / \mathrm{kg}$ bodyweight carbendazim. Administration of carbendazim also decreased the height of the luminal epithelium. A significant decrease in the height of the luminal epithelium was seen at doses of $100 \mathrm{mg} / \mathrm{kg}, 400 \mathrm{mg} / \mathrm{kg}$ and $800 \mathrm{mg} / \mathrm{kg}$ bodyweight carbendazim when compared to the control group. In addition, a decrease in the luminal epithelial height was also observed between carbendazim treatment groups such as: between $25 \mathrm{mg} / \mathrm{kg}$ and $400 \mathrm{mg} / \mathrm{kg} ; 25 \mathrm{mg} / \mathrm{kg}$ and $800 \mathrm{mg} / \mathrm{kg}$; $100 \mathrm{mg} / \mathrm{kg}$ and $400 \mathrm{mg} / \mathrm{kg}$; and between $100 \mathrm{mg} / \mathrm{kg}$ and $800 \mathrm{mg} / \mathrm{kg}$ bodyweight carbendazim.

There was a general decrease in the width of the magnal glands after exposure to carbendazim (Table 1). However, a significant decrease in glandular width was observed at doses of $100 \mathrm{mg} / \mathrm{kg}, 400 \mathrm{mg} / \mathrm{kg}$ and $800 \mathrm{mg} / \mathrm{kg}$ bodyweight carbendazim when compared to the control. In addition, glandular width was significantly decreased between $25 \mathrm{mg} / \mathrm{kg}$ and $100 \mathrm{mg} / \mathrm{kg} ; 25 \mathrm{mg} / \mathrm{kg}$ and $400 \mathrm{mg} / \mathrm{kg}$, as well as between $100 \mathrm{mg} / \mathrm{kg}$ and $800 \mathrm{mg} / \mathrm{kg}$ bodyweight carbendazim. Glandular luminal diameters were also decreased by carbendazim administration. Significant decreases in luminal diameters were detected at doses of $25 \mathrm{mg} / \mathrm{kg}, 100 \mathrm{mg} / \mathrm{kg}, 400 \mathrm{mg} / \mathrm{kg}$ and $800 \mathrm{mg} / \mathrm{kg}$ bodyweight carbendazim when compared to the control group (Table 1). In addition, a significant decrease in luminal diameter was observed between $100 \mathrm{mg} / \mathrm{kg}$ and $800 \mathrm{mg} / \mathrm{kg}$ bodyweight carbendazim treatment groups.

\section{Histological observations \\ Control birds}

The mucosal and submucosal layers of the magnum were visible as primary and secondary folds (Figure 2a). Occasional tertiary folds were also observed. Simple columnar epithelium consisting of ciliated and non-ciliated cells lined the mucosal layer (Figure 2b).

The lamina propria-submucosa contained simple and branched tubular glands (glandulae magni). A scanty, loose connective tissue and a few blood vessels were observed interspaced between the glands. The gland cells contained round nuclei and eosinophilic granular cytoplasm. The lumena of these glands contained eosinophilic secretory material.

A thin tunica muscularis containing inner circular and outer longitudinal layers was present. Loose connective tissue, the tunica serosa, enclosed the magnum. A simple squamous epithelium lined the serosa.

\section{Carbendazim-treated birds}

No morphological changes were observed in the magnum mucosa or in the lamina propria-submucosa post-exposure to carbendazim at doses of $25 \mathrm{mg} / \mathrm{kg}$ and $100 \mathrm{mg} / \mathrm{kg}$ bodyweight.
At a dose of $400 \mathrm{mg} / \mathrm{kg}$ bodyweight, a few degenerating luminal epithelial cells contained pyknotic nuclei (Figure 3a). Isolated areas of glandular atrophy were evident in the lamina propria-submucosa. The atrophic glands were characterised by cells with shrunken cytoplasm, as well as, karyorrhetic and pyknotic nuclei (Figure 3b). In a few areas, degenerating gland cells contained numerous vacuoles, pale cytoplasm, as well as, karyorrhetic and pyknotic nuclei (Figure 3c).

At a dose of $800 \mathrm{mg} / \mathrm{kg}$ bodyweight, vacuolation and cell swelling were observed in degenerating epithelial cells (Figure 4). Hyperaemia and leukocytic infiltrations were occasionally observed in the lamina propria-submucosa underlying the epithelium. In the glandular tissue, numerous vacuoles were observed in degenerating gland cells. No degenerative changes were identified in the tunica muscularis.

\section{Scanning electron microscopy Control birds}

The mucosal layer of the magnum formed longitudinally oriented luminal folds (Figure 5a). Both primary and secondary folds were identified. The luminal epithelium

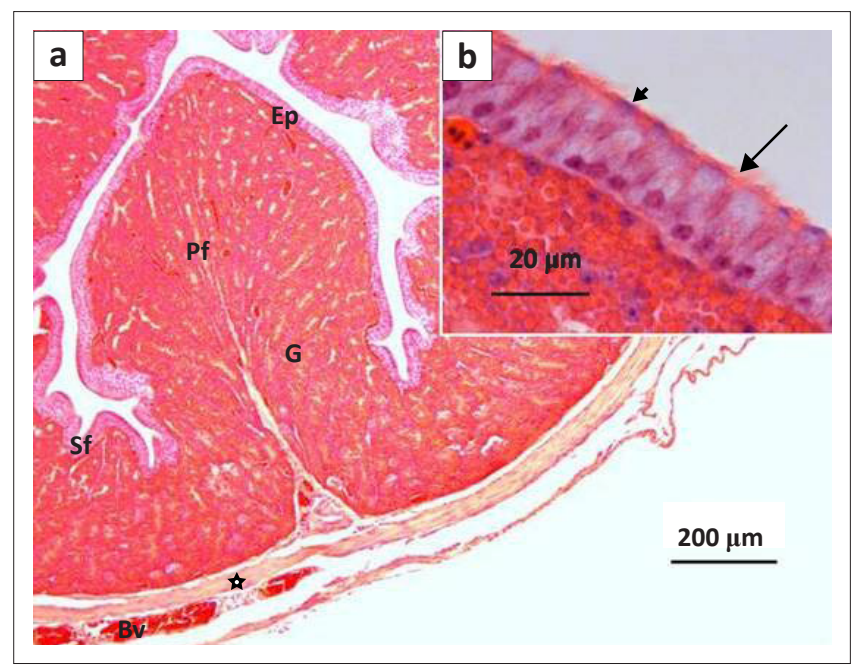

(a) Low magnification showing primary folds (Pf) and secondary fold (Sf); Simple columna epithelium (Ep) lines the mucosa; G, tubular glands; Asterisk, tunica muscularis; Bv, Blood vessel. (b) A higher magnification photomicrograph of the luminal epithelium; Arrow, ciliated cell; Arrowhead, non-ciliated cell.

FIGURE 2: Photomicrographs of the magnum from a control bird.

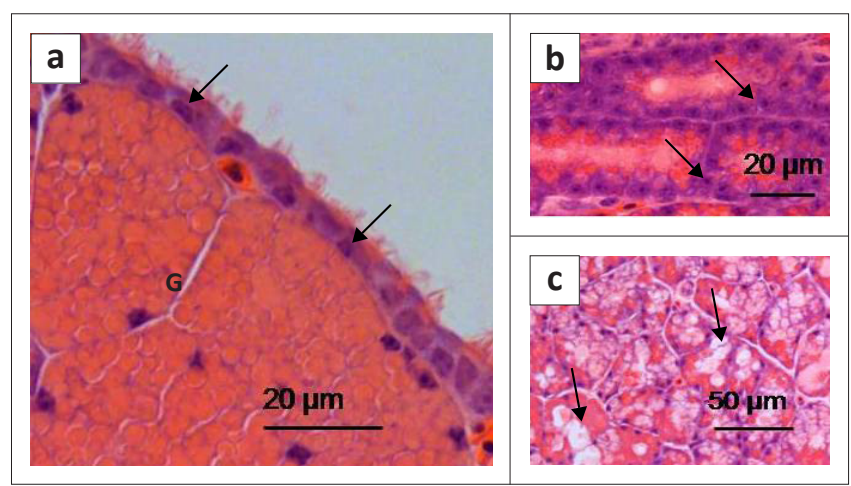

(a) Arrows, pyknotic nuclei; G, tubular glands. (b) Gland cells exhibiting shrunken cytoplasm and pyknotic nuclei (arrows); L, glandular lumen. (c) Gland cells with numerous vacuoles (arrows).

FIGURE 3: Photomicrographs of the magnum from a bird treated with carbendazim at a dose of $400 \mathrm{mg} / \mathrm{kg}$ bodyweight. 
consisted of ciliated and non-ciliated cells. The non-ciliated cells exhibited a dome-shaped apical surface. The surface of the non-ciliated cells was lined by microvilli (Figure $5 b$ ). The ciliated cells, which appeared to be predominant, displayed long cilia. In some instances, the cilia tended to obscure the non-ciliated cells. Round to oval-shaped glandular openings were identified between the epithelial cells.

\section{Carbendazim-treated birds}

No degenerative changes were observed on the magnal mucosal surface of birds treated with carbendazim at doses of $25 \mathrm{mg} / \mathrm{kg}$ or $100 \mathrm{mg} / \mathrm{kg}$ bodyweight. Degenerative changes were observed at doses of $400 \mathrm{mg} / \mathrm{kg}$ and $800 \mathrm{mg} / \mathrm{kg}$ bodyweight. At doses of $400 \mathrm{mg} / \mathrm{kg}$ and $800 \mathrm{mg} / \mathrm{kg}$ bodyweight, isolated areas of deciliation were observed (Figure 6a). In these areas, short ciliary stems, which indicated cilia degeneration, were observed. The non-ciliated cells contained sparsely distributed microvilli (Figure 6b).

\section{Transmission electron microscopy Control birds}

Simple columnar epithelium, composed of ciliated and nonciliated cells, lined the magnum (Figure 7a). The ciliated cells presented electro-lucent cytoplasm. A round to oval nucleus was located in the central cytoplasmic region of the cell. Several cytoplasmic organelles which included cisternae of rough endoplasmic reticulum (RER) and mitochondria were observed adjacent to the nucleus. Golgi complexes and lysosomes were identified in the supranuclear region. A few filaments were observed perinuclearly. On the apical plasma membrane, long cilia lined the ciliated cells (Figure 7a). A few microvilli were observed between the cilia. The cilia were rooted in the cytoplasm and anchored by basal bodies. Supporting the basal bodies were basal feet and striated rootlets.

The non-ciliated cells contained round to irregular-shaped nuclei, which were located basally (Figure 7a). In these cells, the cytoplasm appeared electron dense due to presence of dense particles. Numerous membrane-bound secretory granules were observed in the central and apical cytoplasmic regions (Figure 7a). The secretory granules contained particles of intermediate electron density. Cisternae of RER and mitochondria were observed infranuclearly. The apical plasma membrane was lined by microvilli. Desmosomes linked adjacent epithelial cells along the lateral plasma membranes (Figure 7b).

The luminal epithelial cells in the magnum rested on a granular basal lamina of approximately $78 \mathrm{~nm}$ in thickness. The basal lamina contained a lamina lucida on the epithelial aspect and a lamina densa on the side adjacent lamina propriasubmucosa (Figure 7c).

Simple, branched tubular glands were observed in the lamina propria-submucosa. The gland cells contained round euchromatic nuclei located basally (Figure 7d). The cytoplasm contained numerous cisternae of RER and free

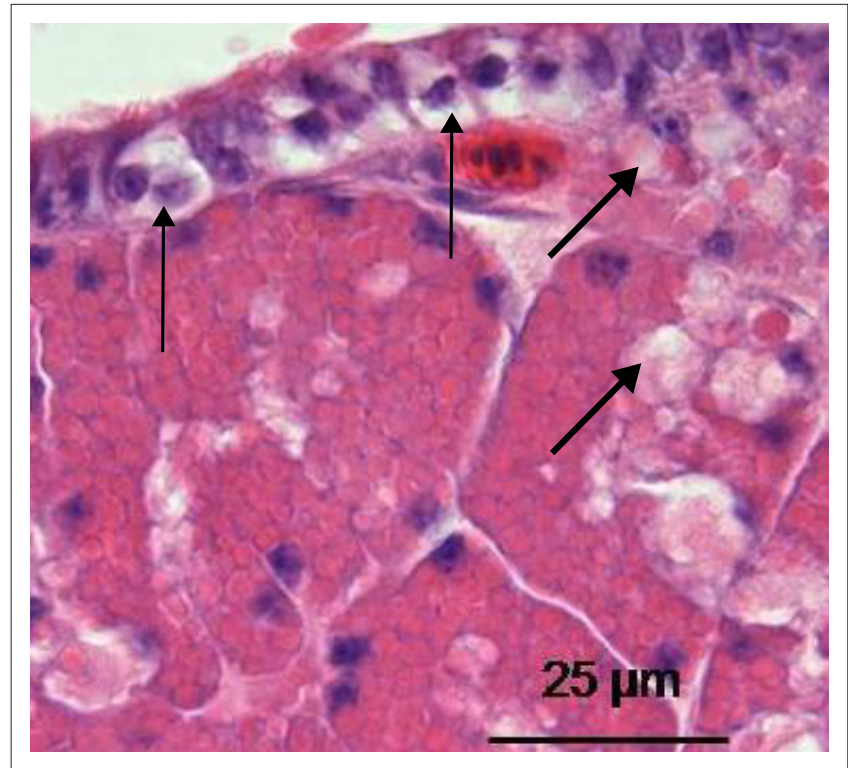

Thin arrows, cells exhibiting pale cytoplasm; Thick arrows, numerous vacuoles in gland cells. FIGURE 4: Photomicrograph of magnum from a bird treated with carbendazim at a dose of $800 \mathrm{mg} / \mathrm{kg}$ bodyweight.

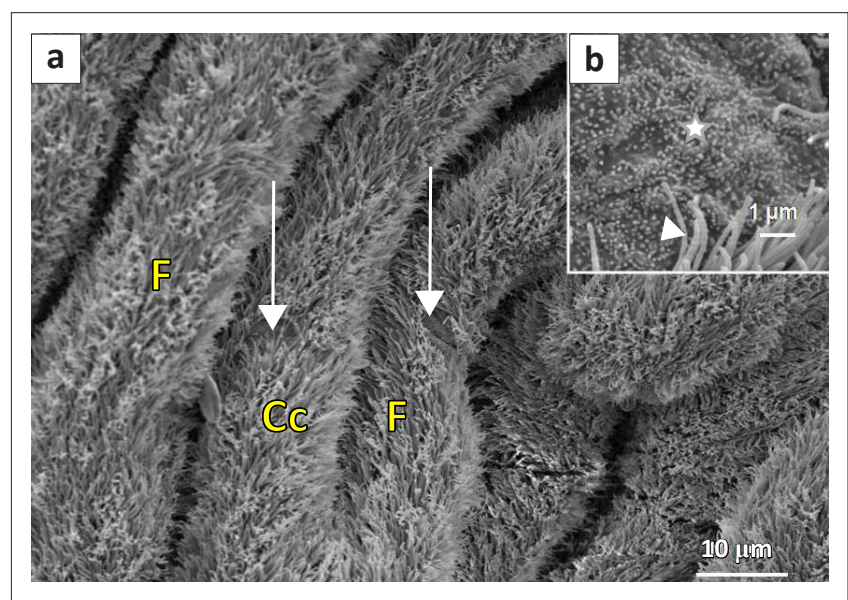

(a) The mucosal surface is thrown into folds (F); Cc, ciliated; Arrows, non-ciliated cells (b) Note the presence of numerous microvilli lining the apical surface of non-ciliated cells
(asterisk); Arrowhead, cilia.

FIGURE 5: Scanning electron photomicrographs of the mucosal surface in the magnum of a control bird.

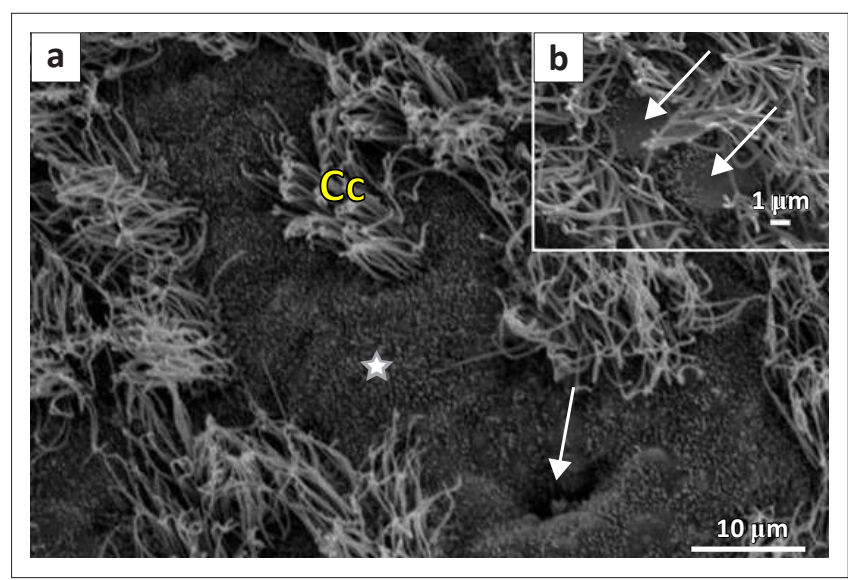

(a) Scanning electron photomicrograph of the mucosal surface of the magnum in a bird treated with carbendazim at a dose of $400 \mathrm{mg} / \mathrm{kg}$ bodyweight; Asterisk, Area of deciliation; Cc, ciliated cells with intact cilia; Arrow, glandular opening. (b) Degenerating non-ciliated cells lined by a few microvilli (arrows).

FIGURE 6: Scanning electron photomicrograph of the mucosal surface of the magnum in a bird treated with carbendazim at a dose of $400 \mathrm{mg} / \mathrm{kg}$ bodyweight. 
ribosomes. In addition, small to medium-sized secretory granules were observed in the apical cytoplasmic regions. Two types of secretory granules were identified: type A and type B. Type A secretory granules contained electron-dense particles (Figure 7d). Type B granules were larger than type A and contained particles of an intermediate electron density. The gland cells contained a few mitochondria which were located perinuclearly. Long and slender microvilli lined the apical plasma membranes. Desmosomes and occasional tight junctions were observed along the lateral plasma membranes. Underlying the magnal glands was a basal lamina of approximately $34 \mathrm{~nm}$ in thickness, which blended with the loose connective tissue of the lamina propria-submucosa. The basal lamina contained homogeneous particles of intermediate electron density. Supporting cells, associated with tubular glands, contained elongated euchromatic nuclei surrounded by scanty cytoplasm of intermediate electron density. Several cisternae of RER and a few mitochondria were observed in the cytoplasm.

\section{Carbendazim treated birds}

Carbendazim did not cause observable morphological changes at doses of $25 \mathrm{mg} / \mathrm{kg}$ and $100 \mathrm{mg} / \mathrm{kg}$ bodyweight. At a dose of $400 \mathrm{mg} / \mathrm{kg}$ bodyweight, degenerating ciliated cells contained pyknotic nuclei. Blebbing of the nuclear membrane was also a notable feature. In a few ciliated cells, crenated nuclei and those exhibiting marginalised nuclear chromatin were observed. At this dose, the ciliated cells were lined by relatively few cilia. Several lysosomes and vacuolated mitochondria were observed in the apical cytoplasmic regions (Figure 8a). Although the basal bodies were intact, the rootlets supporting them were indistinct. Degenerating non-ciliated cells were lined by a few microvilli. In addition, vacuoles and formation of myelin figures were occasionally observed. In these cells, swollen mitochondria were also identified. Desmosomes linking adjacent cells were intact. No degenerative changes were seen in the basal lamina. The lamina was approximately $83 \mathrm{~nm}$ in thickness.

Degenerating glands were characterised by the presence of several vacuoles and swollen mitochondria (Figure $8 b$ ). Cellular junctions along the lateral plasma membranes were intact. Basal lamina which measured approximately $36 \mathrm{~nm}$ in thickness appeared normal. At this dose, supporting cells contained electron-dense cytoplasm. A few vacuoles and degenerating mitochondria were also identified.

At a dose of $800 \mathrm{mg} / \mathrm{kg}$ bodyweight, deciliation and nuclear degeneration were observed in ciliated cells. The observed nuclear degeneration included: pyknosis, margination of nuclear chromatin and blebbing of the nuclear membrane (Figure 9). Although the basal bodies appeared intact, rootlet striations were indistinct. Swollen mitochondria, vacuoles and dilated RER cisternae were observed in the apical cytoplasmic region (Figure 9). A few lysosomes were also identified in this region. Degenerating non-ciliated cells contained pyknotic nuclei and numerous vacuoles. At this dose $(800 \mathrm{mg} / \mathrm{kg})$, the non-ciliated cells contained

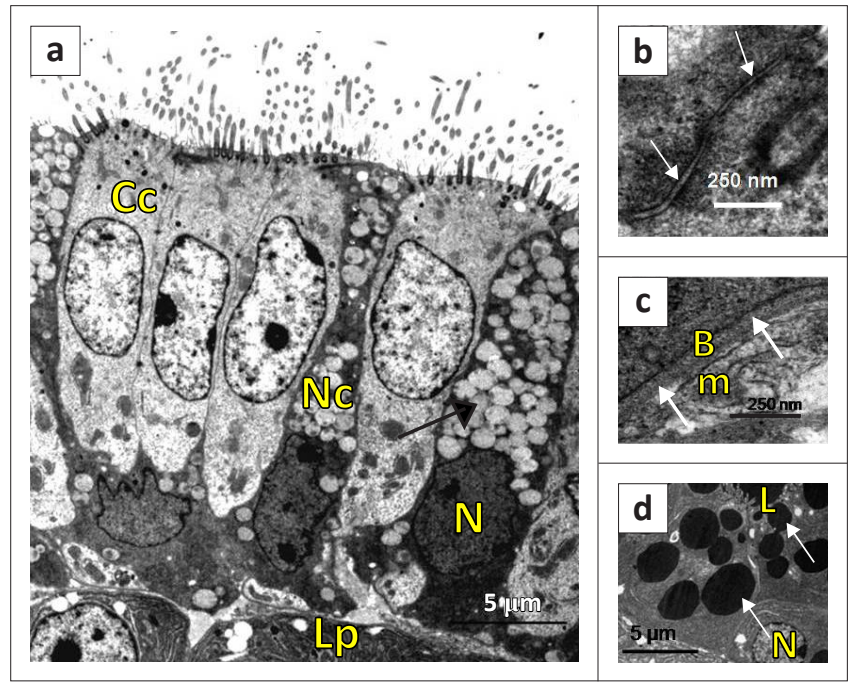

(a) Cc, ciliated cell; Nc, non-ciliated cell in the luminal epithelium; N, basal located nucleus; Arrow, secretory granules. (b) Desmosomes (arrows) along the lateral plasma membranes. (c) Electron photomicrograph of the basal lamina $(\mathrm{Bm})$ underlying the luminal epithelium; The basal lamina displays lamina lucida (thin arrow) and lamina densa (thick arrow) layers; (d) Glandular epithelium in the magnum; N, nucleus; Arrows, type A secretory granules; L, lumen.

FIGURE 7: Transmission electron photomicrographs of the magnum from a control bird.

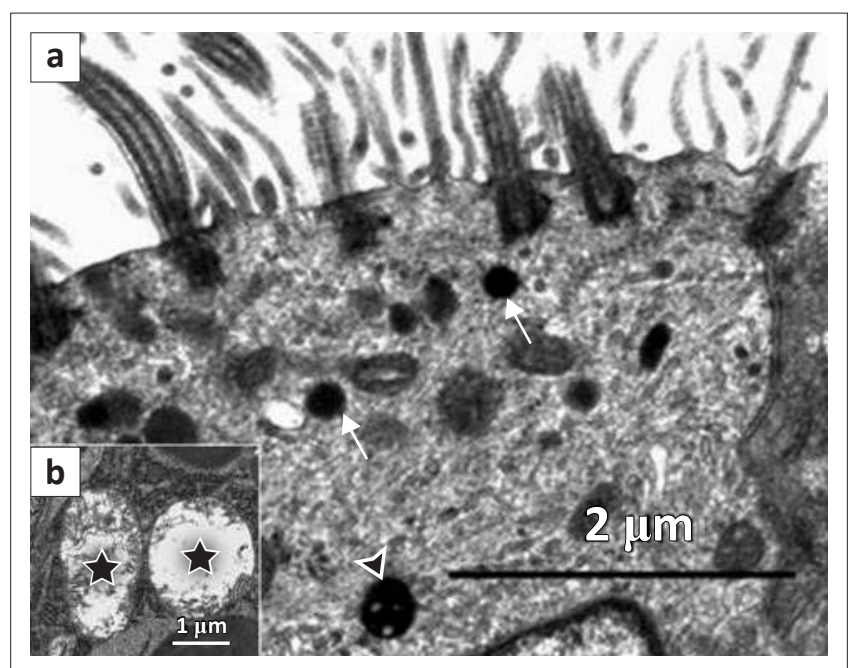

(a) Transmission electron photomicrograph of the apical portion of a degenerating ciliated cell. Several lysosomes (arrows) and vacuolated mitochondria (arrowhead) are concentrated in this region. (b) Electron photomicrograph of degenerating mitochondria. Note the loss of cristae (asterisks) in these mitochondria.

FIGURE 8: Electron micrographs of magnum mucosa from a bird treated with $400 \mathrm{mg} / \mathrm{kg}$ bodyweight carbendazim.

a few secretory granules which were concentrated in the apical regions of the cytoplasm. The degenerating secretory granules contained fragmented particles of an intermediate electron density. Desmosomes, which were observed along the lateral plasma membrane, were intact. The epithelial cells rested on the basal lamina of approximately $70 \mathrm{~nm}$ thick. The structure of the basal lamina was similar to that observed in $400 \mathrm{mg} / \mathrm{kg}$ bodyweight carbendazim-treated group.

Vacuolation and pyknosis were observed in degenerating gland cells (Figure 10a). In addition, swollen mitochondria were also observed in these cells (Figure 10b). Dilated RER cisternae and myelin figures were observed in the perinuclear region of degenerating gland cells (Figure 10c). In some 


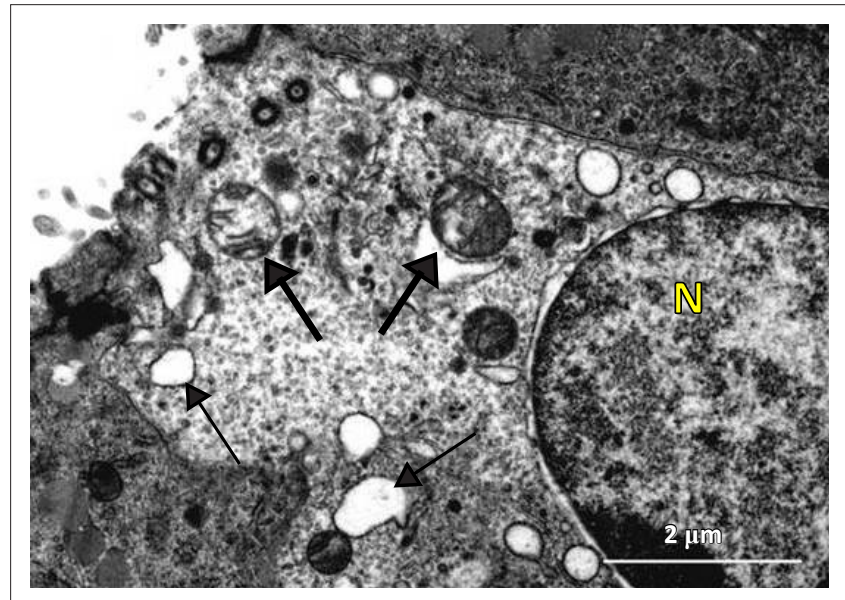

Thick arrows, swollen mitochondria; Thin arrows, dilated cisterns of RER; N, degenerating nucleus exhibiting membrane blebbing.

FIGURE 9: Transmission electron micrograph of degenerating ciliated cell from a bird treated with carbendazim at a dose of $800 \mathrm{mg} / \mathrm{kg}$ bodyweight.

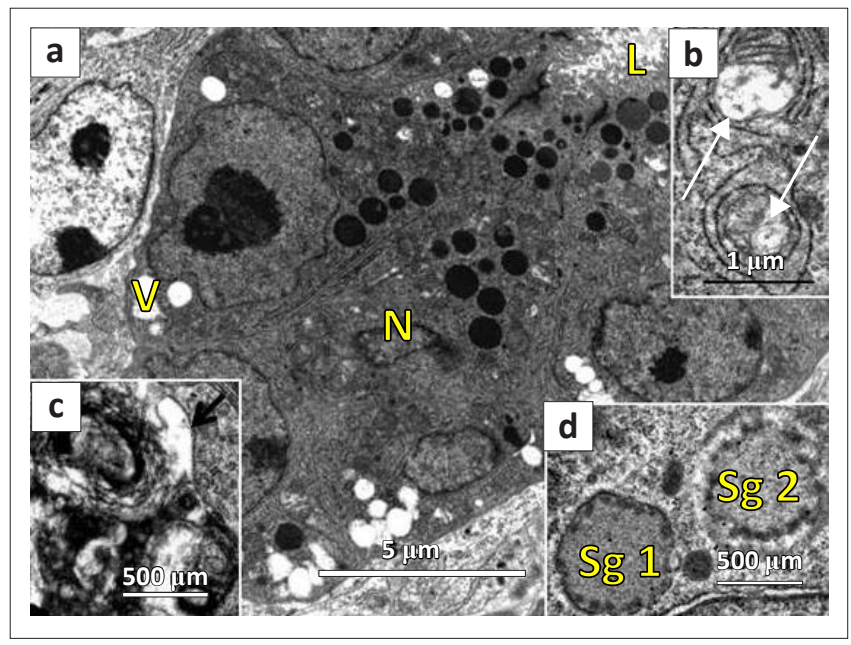

(a) Transmission electron photomicrograph of a tubular gland in the magnum of a bird treated with carbendazim at a dose of $800 \mathrm{mg} / \mathrm{kg}$ bodyweight; $\mathrm{V}$, vacuoles in the degenerating gland cells; L, glandular lumen; N, nucleus. (b) Swollen mitochondria (arrows) in degenerating gland cells. (c) Asterisks, myelin figures; Arrow, dilated cistern of rough endoplasmic reticulum (RER). (d) Electron photomicrograph of degenerating secretory granules ( $S g$ 1\&2). Note the deposition of electron dense granules in the peripheretory (Sg1) and discontinuation of a limiting membrane (Sg 2).

FIGURE 10: Transmission electron photomicrograph of a tubular gland in the magnum of a bird treated with carbendazim at a dose of $800 \mathrm{mg} / \mathrm{kg}$ bodyweight.

instances, degenerating secretory granules were observed. The degenerating secretory granules displayed condensed electron dense particles, which were displaced to the peripheral zone (Figure 10d). In addition, degeneration of the limiting membrane was observed. Relatively few microvilli lined the apical plasma membranes of the gland cells. These microvilli appeared thick when compared to the control group. Desmosomes along the lateral plasma membranes were structurally normal. Invaginations of the basal lamina lining the glandular cells were occasionally observed. At this dose, the basal lamina measured approximately $43 \mathrm{~nm}$ in thickness. Supporting cells contained crenated nuclei. In a few cells, blebbing of the nuclear membrane was observed. Swollen mitochondria and dilated RER cisternae were observed throughout the cytoplasm. A few lysosomes and vacuoles were occasionally identified.

\section{Discussion}

The present study has highlighted the effect of various doses of carbendazim on the morphology of the magnum in the Japanese quail. This appears to be the first report of the effect of cytoskeletal-disrupting fungicide in the female reproductive tract of birds. The results show that carbendazim caused dose dependent morphological changes in the magnum. The minimum toxic dose determined in the current study was $400 \mathrm{mg} / \mathrm{kg}$ bodyweight carbendazim, which caused identifiable morphological changes in this section. Severe morphological changes were apparent when the dose of carbendazim was increased to $800 \mathrm{mg} / \mathrm{kg}$ bodyweight. Similar findings were observed in the male Japanese quail (Aire 2005), as well as in the rat, rabbit and hamster (Mantovani et al. 1998). No morphological changes were observed in birds treated with $25 \mathrm{mg} / \mathrm{kg}$ and $100 \mathrm{mg} / \mathrm{kg}$ bodyweight carbendazim. This could be due to rapid elimination of the carbendazim from body tissues. Elimination of carbendazim from animal tissues is rapid through urine, bile and faeces after hydrolysis and conjugation in the liver (Gardiner et al. 1974). According to Ahdaya, Monroe and Guthrie (1981), no metabolite residues of carbendazim were found in the animal tissues or their products when administered at low doses.

The results of morphometrical study show that, carbendazim reduced the height of mucosal folds, luminal epithelium, as well as glandular width at a dose of $400 \mathrm{mg} / \mathrm{kg}$ bodyweight. This decrease could be due to atrophy of the oviduct as a result of carbendazim toxicity. In addition, reduced height could have also been caused by atrophy due to the androgenic effect exerted by carbendazim exposure. In the rat, carbendazim treatment caused androgenic effects which included atrophy and degeneration of the genital tract (Lu et al. 2004).

In the control birds, histological morphology of the magnum was in agreement with earlier investigations in the Japanese quail by Fitzgerald (1969), as well as Eroschenko and Wilson (1974). It was also similar to the observations made in the domestic fowl (Wyburn et al. 1970), rhea (Parizzi et al. 2008) and brood-parasitic birds (Rueda-Cediel, Kattan \& RamirezPinilla 2008). In contrast to the control birds, the results of carbendazim-treated birds indicated degeneration of luminal and glandular epithelial cells at high doses.

The morphology of the mucosal surface in the magnum of the control birds as revealed by scanning electron microscopy is in consonance with observations made in the domestic fowl by Bakst and Howarth (1975). Loss of cilia by ciliated cells was observed in the mucosal epithelial lining, following carbendazim exposure at doses of $400 \mathrm{mg} / \mathrm{kg}$ and $800 \mathrm{mg} / \mathrm{kg}$ bodyweight. Deciliation could have been caused by weakening of the cilia shaft due to disorganisation of the axial microtubular complex (axoneme). Carbendazim binds the $\beta$-tubulin sub-unit of the microtubule (Burland \& Gull 1984) and consequently inhibits the binding of guanosine 
triphosphate (GTP) to the tubulin (Winder, Strandgaard \& Miller2001). The interaction between carbendazim and axonemal tubulin could have resulted in the disruption of microtubules and consequently defective cilia. Deciliation is a common reaction observed in the epithelial lining of the mucosa when the female reproductive tract is exposed to toxins. For example, loss of cilia was observed in the magnum of pekin ducks fed diets containing high doses of methyl mercury for 28 days (Balachandran, Bhatnagar \& Gcissinger 1985).

TEM results also showed nuclear degenerative changes, such as pyknosis and karyorrhexis in birds treated with carbendazim at doses of $400 \mathrm{mg} / \mathrm{kg}$ and $800 \mathrm{mg} / \mathrm{kg}$ bodyweight. These observations represent chromosomal damage due to carbendazim toxicity. Reports by Styles and Garner (1974), Piati, Mirabini and Chiesara (1994) and Lebailly et al. (1997) support this observation. Styles and Garner (1974) reported chromosomal damage in the rat using cultured cells and following oral exposure to carbendazim and carbendazim parent compound (benomyl). Piati, Mirabini and Chiesara (1994) reported degenerative changes in the nuclei in the hepatocytes of rats exposed to benomyl. According to these authors, the nuclear degeneration presented as increased frequency of micronuclei and chromosomal damage. By using single-cell gel electrophoresis assay, Lebailly et al. (1997) showed chromosomal damage in human lymphocytes post-exposure to carbendazim.

In addition to nuclear degeneration, degenerative changes were also observed in the cytoplasmic organelles, such as: swollen mitochondria, dilated cisternae of RER and increased number of lysosomes and vacuoles. Similar degenerative changes have been observed in the magnum of pekin ducks post-exposure to methyl mercury (Balachandran, Bhatnagar \& Gcissinger 1985). Degeneration of mitochondria indicates stimulation of the apoptotic process through activation of the caspase chain. The increased number of lysosomes and vacuoles observed suggest intracellular clearance of the degenerative material within the cell. This hypothesis is supported by a research report by Chousalkar and Roberts (2008), which stated that vacuoles serve as a reservoir for unutilised secretory material during egg formation.

In conclusion, luminal and glandular epithelial cells in the magnum play a major role in the process of egg formation. Degeneration of these cells, following carbendazim treatment, poses a potential threat to the reproductive activities of exposed birds.

\section{Acknowledgements}

This work was supported by the Deutscher Akademischer Aus-tauschdienst (DAAD doctoral scholarship), the University of Pretoria and the South African Veterinary Foundation (SAVF). The authors thank staff of the University's EM unit and histopathology laboratory for their technical assistance. Mrs W. Olivier is acknowledged for assisting with the schematic drawing of Figure 1.

\section{Competing interests}

The authors declare that they have no financial or personal relationship(s) which may have inappropriately influenced them in writing this article.

\section{Author contributions}

M-C.M. (University of Pretoria) and H.B.G. (University of Pretoria) designed the project and supervised the research. W.H.K. (Sokoine University of Agriculture and University of Pretoria) performed the experiments and prepared the manuscript.

\section{References}

Aire, T.A., 2005, 'Short-term effects of carbendazim on the gross and microscopic features of the testes of Japanese quails (Coturnix coturnix japonica)', Anatomy
and Embryology 210, 43-49. http://dx.doi.org/10.1007/s00429-005-0001-0, and Embryolog

Ahdaya, S.M., Monroe, R.J. \& Guthrie, F.E., 1981, 'Absorption and distribution of intubated insecticides in fasted mice', Pesticide Biochemistry and Physiology 16 38-46. http://dx.doi.org/10.1016/0048-3575(81)90070-5

Bakst, M. \& Howarth, B. (Jr.), 1975, 'SEM preparation and observations of hen's oviduct', Anatomical Record 181, 211-226. http://dx.doi.org/10.1002/ar.1091810205 PMid:1090204

Balachandran, A., Bhatnagar, M.K. \& Gcissinger, H.D., 1985, 'Scanning and transmission electron microscopic studies on the oviducts of pekin ducks fed methyl mercury containing diets', Scanning Electron Microscopy 1, 311-322.

Berg, C., Holm, L., Brandt, I. \& Brunstrom, B., 2001, 'Anatomical and histological changes in the oviducts of Japanese quail, Coturnix coturnix japonica, after embryonic exposure to ethynyloestradiol', Reproduction 121, 155-165. http:// dx.doi.org/10.1530/rep.0.1210155, PMid:11226039

Burland, T.G. \& Gull, K., 1984, 'Molecular and cellular aspects of the interaction of benzimidazole fungicides with tubulin and microtubules', in A.P.J. Trinci \& J.F. Riley (eds.), Mode of action of antifungal agents, p. 299-320, Cambridge University Press, Cambridge.

Carter, S.D. \& Laskey, J.W., 1982, 'Effect of benomyl on reproduction in the male rat', Toxicology Letters 11, 87-94. http://dx.doi.org/10.1016/0378-4274(82)90111-4

Chousalkar, K.K. \& Roberts, J.R., 2008, 'Ultrastructural changes in the oviduct of the laying hen during the laying cycle', Cell Tissue and Research 332, 349-358. http:// dx.doi.org/10.1007/s00441-007-0567-3, PMid:18236079

Davidse, S.D. \& Flach, W., 1977, 'Differential binding of methyl benzimidal-2-yl carbamate to fungal tubulin as a mechanism of resistance to this antimitotic agent in mutant strains of Aspergilus nidulans',Journal of Cell Biology 72, 174-193. http://dx.doi.org/10.1083/jcb.72.1.174, PMid:12184

Davidson, M.F., 1986, 'Histological studies of changes in the magnum of the domestic hen associated with the production of watery white eggs', British Poultry Science 27, 353-354. http://dx.doi.org/10.1080/00071668608416889, PMid:3742272

Drury, R.A.B. \& Wallington, E.A. (eds), 1976, Carleton's histological techniques, 4th edn., Oxford University Press, London.

Eroschenko, V.P. \& Wilson, W.O., 1974, 'Histological changes in the regressing reproductive organs of sexually mature male and female Japanese quail', Biology of Reproduction 11, 168-179. http://dx.doi.org/10.1095/biolreprod11.2.168, PMid:4457133

Finnish National Board of Health, 1982, 'The toxicity of the benzimidazole type fungicides: benomyl, carbendazim and thiophanate-methyl', Second report, Finnish National Board of Health, Helsinki.

Fitzgerald, T.C. (ed.), 1969, The coturnix quail: Anatomy and histology, lowa State University Press, Ames.

Gardiner, J.A., Kirkland, J.J., Klopping, H.L. \& Sherman, H., 1974, 'Fate of benomyl in animals', Journal of Agriculture and Food Chemistry 22, 419-427. http://dx.doi. org/10.1021/jf60193a046, PMid:4840504

Goldman, J.M., Rehinberg, G.L., Cooper, R.L., Gray, L.E., Hein, J.F. \& McElroy, W.K., 1989, 'Effects of the benomyl metabolite carbendazim on the hypothalamicpituitary reproductive axis in the male rat', Toxicology 57, 173-182. http://dx.doi. org/10.1016/0300-483X(89)90163-7

Hess, R.A., Moore, B.J., Linder, R.E. \& Abuel-Atta, A.A., 1991, 'The fungicide benomyl (methyl-1-(butylcarbamate)-2-benzimidazolecarbamate) causes testicular dysfunction by inducing sloughing of germ cells and occlusion of efferent ductules', Fundamentals of Applied Toxicology 17, 733-745. http://dx.doi. org/10.1016/0272-0590(91)90181-3

International Program on Chemical Safety (IPCS), 1986, 'Report No. 64: Environmental health criteria for carbamate pesticides: A general introduction', www.inchem.org

Lebailly, P., Vigreux, C., Godard, T., Sichel, F., Bar, E., Letalaer, J.Y., Henry-Amar, M. \& Gauduchon, P., 1997, 'Assessment of DNA damage induced in vitro by etoposite and two fungicides (carbendazim and chlorothalonil) in human lymphocytes with the comet assay', Mutation Research 375, 2005-217. http://dx.doi.org/10.1016/ S0027-5107(97)00015-8 
Lim, J. \& Miller, M.G., 1997, 'The role of the benomyl metabolite carbendazim in benomyl-induced testicular toxicity', Toxicology and Applied Pharmacology 142 benomyl-induced testicular toxicity', Toxicology and Applied Pharmaco
401-410. http://dx.doi.org/10.1006/taap.1996.8042, PMid:9070363

Lu, S-Y., Liao, J-W., Kuo, M-L., Wang, S-C., Hwang, J-S. \& Ueng, T-H., 2004, 'Endocrine disrupting activity in carbendazim-induced reproductive and developmental toxicity in rats', Journal of Toxicology and Environmental Health 67, 1501-1515. http://dx.doi.org/10.1080/15287390490486833, PMid:15371226

Mantovani, A., Maranghi, F., Ricciardi, C., Macri, C., Stazi, A.V., Attias, L. \& Zappini, G.A., 1998, 'Developmental toxicity of carbendazim: Comparison of no-observedadverse-effect level and benchmark dose approach', Food and Chemical Toxicology 36, 37-45. http://dx.doi.org/10.1016/S0278-6915(97)00116-6

Palmiter, R.D. \& Gutman, G.A., 1972, 'Fluorescent antibody localization of ovalbumin, conalbumin, ovomucoid and lysozyme in chick oviduct magnum', The Journal of Biological Chemistry,6459-6461.

Parizzi, R.C., Santos, J.M., Oliviera, M.F., Maia, M.O., Sousa, J.A., Miglino, M.A. \& Santos, T.C., 2008, 'Macroscopic and microscopic anatomy of the oviduct in the sexually mature hea (Rhea americana)', Anatomia Histologia Embryologia 37, 169-176. http://dx.doi.org/10.1111/j.1439-0264.2007.00822.x, PMid:18070241

Piati, E., Mirabini, L. \& Chiesara, E., 1994, 'Increase of micronucleus frequency in cultured rat hepatocytes treated in vitro with benomyl and pirimiphos-methy separately and in mixture', Mutation Research 324, 59-64. http://dx.doi. separately and in mixture, Mutation
Pico, Y., La Farre, M., Soler, C. \& Barcelo, D., 2007, 'Identification of unknown pesticides in fruits using ultra-performance liquid chromatography-quadrupole time-of-flight mass spectrometry Imazilil as a case study of quantification' Journal of Chromatography 1176, 123-134. http://dx.doi.org/10.1016/j. chroma.2007.10.071, PMid:18021786

Rueda-Cediel, P., Kattan, G. \& Ramirez-Pinilla, M.P., 2008, 'Ovarian and oviductal morphology of a brood-parasitic bird, Molothrus bonariensis (Passerifomes, Icteridae)' Acta Zoologica 89, 261-276. http://dx.doi.org/10.1111/j.14636395.2007.00315.

Still, G.G. \& Mansager, E.R., 1975, 'Alfalfa metabolism of propham', Pesticide Biochemical Physiology 5, 515-522. http://dx.doi.org/10.1016/0048 3575(75)90026-7

Styles, J.A. \& Garner, R., 1974, 'Benzimidazole carbamate methyl ester - Evaluation of its effects in vivo and in vitro', Mutation Research 26, 177-187. http://dx.doi. org/10.1016/S0027-5107(74)80072-2

Winder, B.S., Strandgaard, C.S. \& Miller, M.G., 2001, 'The role of GTP binding and microtubule-associated proteins in the inhibition of microtubule assembly by
carbendazim', Toxicological Science 59, 138-146. http://dx.doi.org/10.1093/ toxsci/59.1.138, PMid:11134553

Wyburn, G.M., Johnston, H.S., Draper, M.H. \& Davidson, M.F., 1970, 'The fine structure of the infundibulum and magnum of the oviduct of Gallus domesticus', Quarterly Journal of Experimental Physiology 55, 213-232. PMid:5201499 